\title{
von Willebrand Factor Gene Polymorphism in Preeclampsia Pregnant at Medan, Indonesia
}

\author{
Dewi Indah Sari Siregar ${ }^{1 * \mathbb{D}}$, Muhammad Fidel Ganis Siregar ${ }^{2}$ D, Gontar Alamsyah Siregar ${ }^{3}$, Syah Mirsya Warli ${ }^{4}$ D \\ ${ }^{1}$ Departement of Clinical Pathology, Faculty of Medicine, Universitas Sumatera Utara, Medan, Indonesia; ${ }^{2}$ Departement of \\ Obstetrics and Gynecology, Faculty of Medicine, Universitas Sumatera Utara, Medan, Indonesia; ${ }^{3}$ Departement of Internal \\ Medicine, Faculty of Medicine, Universitas Sumatera Utara, Medan, Indonesia; ${ }^{4}$ Departement of Urology, Faculty of Medicine, \\ Universitas Sumatera Utara, Medan, Indonesia
}

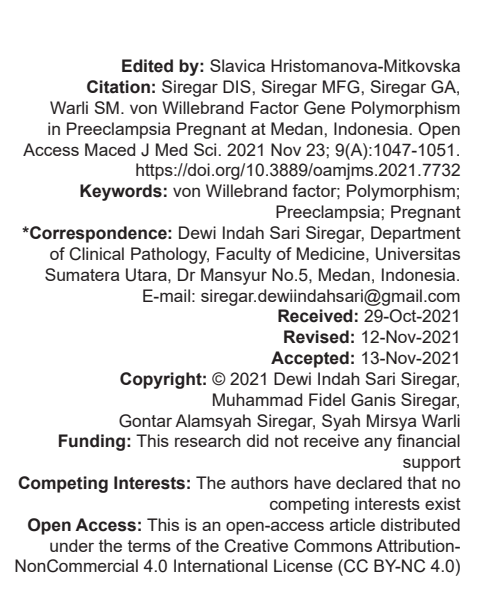

\begin{abstract}
BACKGROUND: von Willebrand Factor (VWF) is a large glycoprotein mediating hemostasis and thrombosis. The roles of VWF are platelets adhesion to sites of vascular damage and stabilization of coagulation factor VIII.

AIM: This study aimed to analyze the polymorphism of the VWF gene on preeclampsia (PE) in pregnancy in Medan, Indonesia.

MATERIALS AND METHODS: DNA was amplified using the polymerase chain reaction and was electrophoresed in agarose $2 \%$. Electrophoresis results were detected using Gel Doc 1000 (Biorad, USA). The sequencing method was used to identify polymorphism from vWF gene.

RESULTS: From 50 samples of PE patients, the g.93308C >T vWF gene polymorphism was found with the percentage of TT, CT, and CC genotypes as $50 \%, 42 \%$, and $8 \%$, respectively.

CONCLUSION: The c.93308C>T vWF gene polymorphism was found in the genotype percentage of homozygous $\mathrm{TT}$, and heterozygote CT was greater than wild-type CC.
\end{abstract}

\section{Introduction}

von Willebrand Factor (vWF) is a large glycoprotein mediating hemostasis and thrombosis. vWF plays a role in platelets adhesion during vascular injury and stabilization of coagulation factor VIII. Deficiency of vWF in hemostasis leads to congenital bleeding disorder or von Willebrand disease (vWD). vWF also plays roles in blood vessels such as inflammation, permeability, and angiogenesis. A thrombotic event in thrombotic thrombocytopenic purpura is characterized by deposition of VWF and platelet thrombus in microvascular leading to vascular occlusion, tissue ischemia, organ failure, and even death [1], [2].

VWF is synthesized in endothelial cells and megakaryocytes and stored in Weibel-Palade bodies and granules [3]. The vWF gene is located on the short arm of chromosome 12, locus 12p13.3, spans 178 kilobases and consists of 52 exons and 51 introns [4]. Genetic variation is an alteration in the sequence of DNA nucleotides that causes changes in protein function. Genetic variation of vWF has been identified in 2728 single nucleotide polymorphisms (SNPs), 91 insertions and deletions in various ethnicity [5]. Genetic variation of VWF gene has been reported to be associated with several diseases of vascular occlusion such as deep vein thrombosis [6], heart disease [7], vWD types 1 and 2 [8], [9], hypertension, and preeclampsia (PE). A previous study by Sun et al. (2009) found Msp I vWF gene polymorphism in intron 19 associated with the prevalence and severity of PE [10]. In pregnancy, vWF levels increase together with factor VIII starting from the first trimester along with the gestational age [11].

$\mathrm{PE}$ is a pregnancy-specific complication characterized by hypertension, proteinuria, or other signs of organ dysfunction. This abnormality is seen after 20 weeks of gestation with previously normotensive patients [12]. PE is associated with extensive endothelial activation, increased inflammatory response, and placenta abnormalities. Endothelial cell activation causes increasing levels of soluble thrombomodulin, E-selectin, and vWF. Previous studies have shown increased levels of VWF antigen in PE patients characterized by endothelial cell activation [13]. In severe complicated PE cases, an increased level 
of active vWF is associated with acute endothelial cell activation and endothelial dysfunction [14]. Increased level of vWF antigen is associated with genetic variation of VWF gene [5], [15]. Based on the description above, the researchers aimed to analyze the genetic variation of the VWF gene on PE in Medan, Indonesia. The researcher hopes this study can be used as a reference in determining several diseases for future studies.

\section{Methods}

\section{Ethics}

This research has been approved by Universitas Sumatera Utara (USU) Health Research Ethics Commission (No. 892/KEP/USU/2021).

\section{Study design}

This is a descriptive analytic study with a crosssectional approach and conducted on 50 PE patients. Calculation of the number of sample was obtained using the prevalence value from the previous study in China. PE patients were picked from three different hospitals; $H$. Adam Malik Central General Hospital; Pirngadi Hospital and Sundari Hospital in Medan. The inclusion criteria for this study were pregnant women with clinically diagnosed $\mathrm{PE}$ and willing to provide informed consent which was complied with study procedures. The diagnosis of PE was determined by obstetricians with systolic blood pressure $\geq 140 \mathrm{mmHg}$ and/or diastolic blood pressure $\geq 90 \mathrm{mmHg}$ after 20 weeks of gestation until 2 weeks postpartum accompanied by proteinuria ( $24 \mathrm{~h}$ excretion $\geq 300 \mathrm{mg}$ ). In the absence of proteinuria, PE was diagnosed with newonset hypertension and new onset of any severe features, namely thrombocyte count $\langle 100,000 / \mu$ l, serum creatinine $>1.1 \mathrm{mg} / \mathrm{dl}$, or double the concentration in the absence of other renal diseases, serum liver transaminases $2 x$ normal, pulmonary edema, cerebral/visual symptoms [16]. The exclusion criteria for this study were the presence of systemic disease, chronic disease, and previous abnormal conditions in the study participants.

\section{DNA extraction and sequencing}

The $5 \mathrm{ml}$ blood sample was taken and labeled in a vacuum tube, then centrifuged at $2500 \mathrm{rpm}$ for 15 min to obtain a leukocyte buffy coat. Extraction of DNA from leukocytes buffy coat was done by using DNA extraction and purification kit (The Wizard Genomic DNA Purification Kit, Promega, USA). DNA purification was measured using spectrophotometer nano drops. This process was carried out at the Integrated Laboratory of USU, Faculty of Medicine. The ratio of purity DNA must be from 1.8 to 2.0; concentration results were at least $30 \mu \mathrm{l}$. Other than that was excluded from the study.
The polymerase chain reaction $(\mathrm{PCR})$ reaction was done. The concentration of forward primer (5'-TGGCCGCG- TGCACCCTCACTCCACC-3') and reverse primer (5'-AGGGCTTTAG ATCAGT- CACT GTGGCCCT-3') each 1 uL, GoTaq® Green Master Mix (Promega, USA) $12.5 \mathrm{uL}$, DNA sample $2 \mathrm{uL}$, and $\mathrm{dH} 2 \mathrm{O}$ $8.5 \mathrm{uL}$. The primers used referred to a previous study [10]. PCR was carried out with an initial denaturation step at $94^{\circ} \mathrm{C}$ for $5 \mathrm{~min}$, continued with 35 cycles of denaturation at $94^{\circ} \mathrm{C}$ for $30 \mathrm{~s}$, elongation at $72^{\circ} \mathrm{C}$ for $30 \mathrm{~s}$, annealing at $57^{\circ} \mathrm{C}$ for $30 \mathrm{~s}$, and final cycle at $72^{\circ} \mathrm{C}$ for $5 \mathrm{~min}$. DNA was electrophoresed in agarose $2 \%$ at 70 volts for 90 min to determine isolation quality. Furthermore, electrophoresis results were detected using Gel Doc 1000 (Biorad, USA) to be visualized with ultraviolet light.

Pure DNA samples were sent to Malaysia's $1^{\text {st }}$ Base laboratory. The sequencing results of vWF polymorphism gene were analyzed using 4Peaks program (A. Griekspoor and Tom Groothuis, nucleobytes.com). The sequencing results were forward and reverse nucleotide base pairs in the form of ab1 and seq format. vWF gene sequence data were compared with gene bank number NG_009072.2 using the BLAST program from NCBI. The homology assessment of the sample isolates against the reference sequence can be seen from the percentage value of its identity, a value of $100 \%$ indicating that the sample isolate sequence is exactly the same as the reference isolate, while the lowest percentage (95\%) is still considered good.

\section{Statistical analyses}

The obtained data were analyzed using SPSS version 25 computer software. Data were presented in the form of figures and tables of frequency distribution. The $\chi^{2}$ test was used to determine whether the observed genotype distributions confirm to the Hardy-Weinberg equilibrium expectation (HWE).

\section{Results}

This study identified gene variations of vWF in 50 PE patients in Medan, Indonesia. Characteristics of $\mathrm{PE}$ patients based on age, systolic blood pressure, diastolic blood pressure, platelets, platelet distribution width and mean platelet volume are shown in the median, minimum and maximum values in Table 1.

The DNA electrophoresed results from 50 samples showed in Figure 1.

One of the vWF gene polynucleotide sequencings showed in Figure 2. The positioning of mutations in vWF samples was carried out using the gene reference NG_009072.2. Sequencing was found 


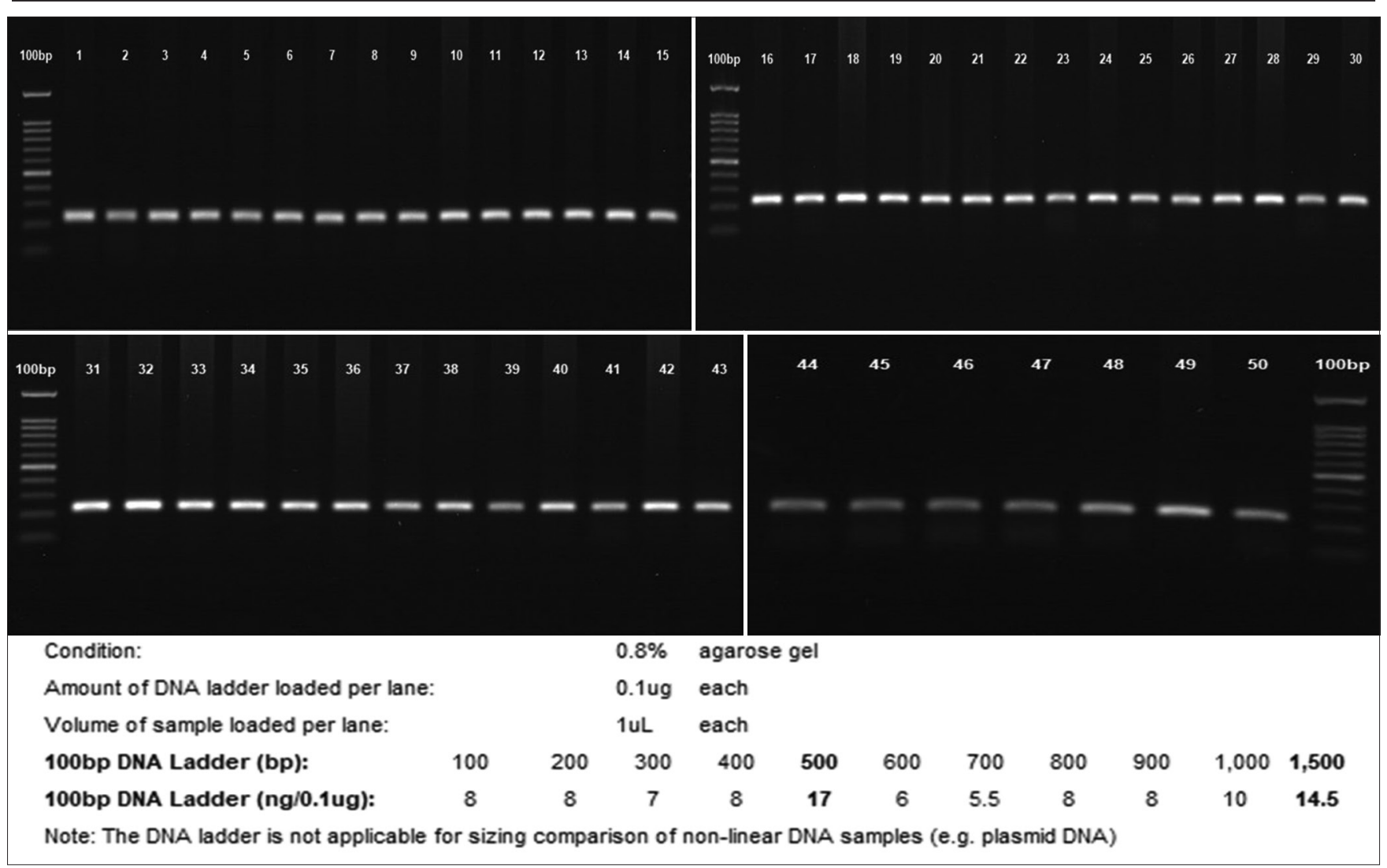

Figure 1: von Willebrand Factor gene amplification results from 50 samples (226 bp)

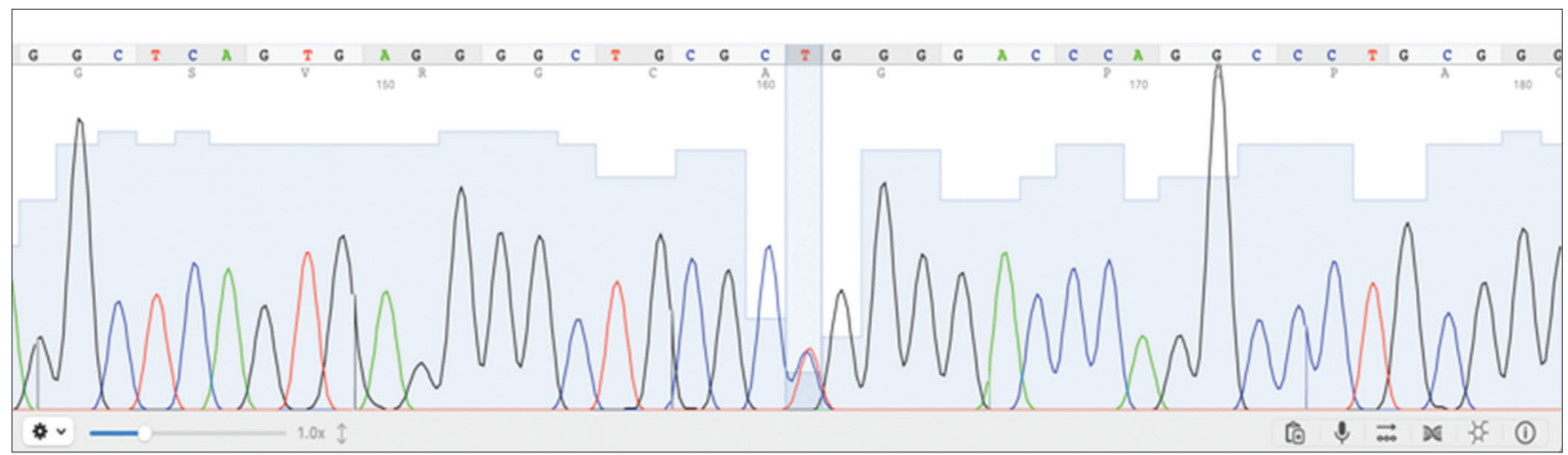

Figure 2: Double peak in von Willebrand Factor gene

double peaks coding for substitution of cytosine (C) to thymine $(T)$ at nucleotide number 93308 indicated as heterozygous subjects.

\section{Table 1: Characteristic of study participants}

\begin{tabular}{lccc}
\hline Characteristics & $\mathrm{n}$ & Median & Min-Max \\
\hline Age (years) & 50 & 30.5 & $21-42$ \\
Systolic blood pressure $(\mathrm{mmHg})$ & 50 & 160 & $128-200$ \\
Diastolic blood pressure $(\mathrm{mmHg})$ & 50 & 100 & $80-120$ \\
Platelet count $\left(\times 10^{3} / \mathrm{mm}^{3}\right)$ & 50 & 299.5 & $150-1098$ \\
PDW $(\mathrm{fl})$ & 50 & 13 & $8.4-18.7$ \\
MVP $(\mathrm{fl})$ & 50 & 11.05 & $8.5-13.1$ \\
\hline
\end{tabular}

In this study, the VWF gene mutation $\mathrm{9} .93308 \mathrm{C}>\mathrm{T}$ was found in 46 samples. The results of VWF gene sequencing in this study can be seen in Table 2 .

Our results suggested that the genotype distribution of vWF gene polymorphism g.93308C $>T$ did not significantly deviate from the HWE $(p>0.05)$.
The genotype of the polymorphism was CC type $8 \%$ $(n=4)$, CT type $42 \%(n=21)$ and TT type $50 \%(n=25)$. The $T$ allele frequencies are $71 \%$ (Table 2 ).

Table 2: Genotype distribution of vWF in preeclampsia pregnant

\begin{tabular}{lllllll}
\hline Name & \multicolumn{2}{l}{ Genotypes } & & \multicolumn{2}{c}{ Allele frequencies } \\
\cline { 2 - 3 } & CC & CT & TT & & C \\
\hline Observed number (\%) & $4(8)$ & $21(42)$ & $25(50)$ & & 0.29 & 0.71 \\
Expected number & 4.2 & 20.6 & 25.2 & & \\
\hline
\end{tabular}

Expected number

\section{Discussion}

PE is a multisystem disorder in pregnancy that complicates $3-5 \%$ of pregnancies. It is the 
leading cause of mortality and morbidity in pregnancy worldwide. Genetic factors play an essential role in PE, but the exact pattern of inheritance is still unknown. One of the genetic factors known to play a role in PE is the genetic variation of vWF. The vWF gene in human is an important component of the hemostasis system. There are at least 33 types of polymorphisms of the vWF gene. One of the polymorphisms of the vWF gene is Msp1 which is found in several diseases [6], [7], [8], [9]. Msp I vWF gene polymorphism is located in intron 19 associated with platelets and coagulation factor VIII. This leads to a genetic mutation of vWF that has the potential to cause PE [10], [17].

The present study found a substitution of cytosine $(C)$ to thymine $(T)$ at vWF gene that indicates heterozygous mutant CT and homozygous mutant TT. In this study, we have not been able to determine whether there is an amino acid change in the $\mathrm{g} .93308 \mathrm{C}>\mathrm{T}$ substitution. This is due to the incomplete reference sequence showing the exon and intron regions of the vWF gene.

In this study, the homozygous TT and heterozygous CT were higher than the homozygous wildtype CC (50\% vs. $42 \%$ vs. $8 \%$ ). This shows that in patients with $\mathrm{PE}$, the percentage of mutant genotypes is higher than the wildtype. This result is different from the previous study conducted by Sun et al., 2009 where the genetic variation of the Msp1 vWF gene was taken from 70 samples of PE patients who had homozygous mutations $(\mathrm{M}+/ \mathrm{M}+)$, heterozygous mutations $(\mathrm{M}+/ \mathrm{M}-)$, homozygous wildtype (M-/M-) were $22.9 \%$ versus $45.7 \%$ versus $31.4 \%$, respectively [10].

This study suggests that for PE pregnant women in Medan-Indonesia, the allele and genotype frequencies of the VWF gene polymorphism are in HWE. Thus, we can expect these allele frequencies to remain constant over time, ensuring genetic variation of vWF gene polymorphism in the population. Distribution of $\mathrm{T}$ allele was found higher than the C allele (71\% vs. $29 \%$ ).

The distribution of the polymorphism of the vWF gene in other populations around the world is shown in Table 3.

Based on Table 3, it was found that several polymorphism genes of vWF in populations of various countries in several diseases. The polymorphism gene of vWF in that population was not found to have Msp1 polymorphisms and PE population. Until today, we have only found Msp1 SNPs in patients with PE based on Sun et al. 2009 research [10]. Wang et al. (2013) stated that allelic diversity and polymorphisms gene of the vWF are very complex in various populations [5]. A novel vWF gene polymorphism was found in the Turkish population with SNP 4483C>T [23].

This study was an initial study of the polymorphism gene of VWF in PE patients in Indonesia, especially in Medan. It is known that data on the polymorphism gene of VWF in Indonesia is still very limited. Further research is needed to confirm the findings of the current study and address the study's genetic-related weaknesses.

Table 3: Distribution of vWF gene polymorphism in various populations and diseases

\begin{tabular}{|c|c|c|c|c|}
\hline vWF gene polymorphism & Population & Disease & Genotype & $\%$ \\
\hline \multirow[t]{3}{*}{$4975 \mathrm{C}>\mathrm{T}[18]$} & Pakistan & von Willebrand's disease & $\mathrm{CC}$ & 38 \\
\hline & & & CT & 38 \\
\hline & & & TT & 24 \\
\hline \multirow[t]{3}{*}{$3445 \mathrm{~T}>\mathrm{C}[18]$} & Pakistan & von Willebrand's disease & TT & 19 \\
\hline & & & TC & 45 \\
\hline & & & $\mathrm{CC}$ & 36 \\
\hline \multirow[t]{3}{*}{$7603 \mathrm{C}>\mathrm{T}[18]$} & Pakistan & von Willebrand's disease & $\mathrm{CC}$ & 19 \\
\hline & & & TC & 38 \\
\hline & & & TT & 43 \\
\hline \multirow[t]{3}{*}{$1185 A>G[19]$} & Brazil & Coronary artery disease & AA & 18.1 \\
\hline & & & AG & 50 \\
\hline & & & GG & 31.9 \\
\hline \multirow[t]{3}{*}{ Smal [20] } & China & Ischemic stroke & $\mathrm{CC}$ & 26.4 \\
\hline & & & $\mathrm{CT}$ & 41.5 \\
\hline & & & TT & 32.1 \\
\hline \multirow[t]{3}{*}{ Smal [20] } & China & Myocardial infarction & $\mathrm{CC}$ & 13.6 \\
\hline & & & $\mathrm{CT}$ & 54.5 \\
\hline & & & TT & 31.8 \\
\hline \multirow[t]{2}{*}{$1381 \mathrm{~A}>\mathrm{T}[21]$} & China & Coronary heart disease & GG & 70 \\
\hline & & & AG & 30 \\
\hline \multirow[t]{3}{*}{$1185 A>G$ [22] } & Gaza & Coronary heart disease & AA & 32.9 \\
\hline & & & AG & 42.4 \\
\hline & & & GG & 24.7 \\
\hline
\end{tabular}

\section{Conclusion}

This study concluded that from fifty pregnant subjects with PE, mutations of VWF were found in genotype percentage of homozygous TT and heterozygote CT was greater than wild type CC $(92 \%$ vs. $8 \%$ ) and the allele frequency was $71 \%$. We have not been able to determine whether there is an amino acid change in the $\mathrm{g} .93308 \mathrm{C}>\mathrm{T}$ due to the incomplete reference showing the exon and intron regions of the vWF gene.

\section{Acknowledgments}

The researchers are thankful to Head Director of $\mathrm{H}$. Adam Malik Central General Hospital, Pirngadi Hospital and Sundari Hospital and all the participants who contributed to this study.

\section{References}

1. Randi AM, Smith KE. Castaman G. von Willebrand factor regulation of blood vessel formation. Blood. 2018;132(2):13240. https://doi.org/10.1182/blood-2018-01-769018 PMid:29866817

2. Chen J, Chung DW. Inflammation, von Willebrand factor, and ADAMTS13. Blood. 2018;132(2):141-7. https://doi.org/10.1182/ blood-2018-02-769000. 


\section{PMid:29866815}

3. Stepanian A, Cohen-Moatti $M$, Sanglier $T$, Legendre $P$ Ameziane $\mathrm{N}$, Tsatsaris $\mathrm{V}$, et al. von Willebrand factor and ADAMTS13: A candidate couple for preeclampsia pathophysiology.ArteriosclerThromb VascBiol. 2011;31(7):17039. https://doi.org/10.1161/ATVBAHA.111.223610 PMid:21512165

4. Peyvandi F, Garagiola I, Baronciani L. Role of von Willebrand factor in the haemostasis. Blood Transfus. 2011;9 Suppl 2:s3-8. https://doi.org/10.2450/2011.002S

PMid:21839029

5. Wang QY, Song J, Gibbs RA, Boerwinkle E, Dong JF, Yu FL. Characterizing polymorphisms and allelic diversity of von Willebrand factor gene in the 1000 Genomes. J Thromb Haemost. 2013;11(2):261-9. https://doi.org/10.1111/jth.12093 PMid:23216583

6. Smith NL, Rice KM, Bovill EG, Cushman M, Bis JC, McKnight B, et al. Genetic variation associated with plasma von Willebrand factor levels and the risk of incident venous thrombosis. Blood. 2011;117(22):600711. https://doi.org/10.1182/blood-2010-10-315473 PMid:21163921

7. van Schie MC, de Maat MP, Isaacs A, van Duijn CM, Deckers JW, Dippel DW, et al. Variation in the von Willebrand factor gene is associated with von Willebrand factor levels and with the risk for cardiovascular disease. Blood. 2011;117(4):1393-9. https://doi. org/10.1182/blood-2010-03-273961

PMid:20940418

8. Johansson AM, Halldén C, Säll T, Lethagen S. Variation in the VWF gene in Swedish patients with Type 1 von Willebrand disease. Ann Hum Genet. 2011;75(4):447-55. https://doi.org/1 $0.1111 / \mathrm{j} .1469-1809.2011 .00652$

PMid:21534937

9. Freitas SD, Rezende SM, de Oliveira LC, Prezotti AN, Renni MS, Corsini CA, et al. Genetic variants of VWF gene in Type 2 von Willebrand disease. Haemophilia. 2019;25(2):e78-85. https:// doi.org/10.1111/hae.13714 PMid:30817071

10. Sun $\mathrm{C}$, Chen $\mathrm{Y}$, Zhang W, Yu S. Association between von Willebrand factor gene polymorphism and preeclampsia. J Perinat Med. 2009;37(1):36-42. https://doi.org/10.1515/ JPM.2009.018

PMid:19021456

11. Castaman G. Changes of von Willebrand factor during pregnancy in women with and without von Willebrand disease. Mediterr J Hematol Infect Dis. 2013;5(1):e2013052. https://doi. org/10.4084/MJHID.2013.052 PMid:23936623

12. Peracoli JC, Borges VT, Ramos JG. Pre-eclampsia/eclampsia Rev Bras Ginecol Obstet. 2019;41(5):318-32. https://doi. org/10.1055/s-0039-1687859
PMid:31181585

13. Aref S, Goda $H$. Increased VWF antigen levels and decreased ADAMTS13 activity in preeclampsia. Hematology. 2013;18(4):237-41. https://doi.org/10.1179/16078454 $12 Y .0000000070$ PMid:23433535

14. Kim MA, Han GH, Kwon JY, Kim YH. Clinical significance of platelet-to-lymphocyte ratio in women with preeclampsia. Am J Reprod Immunol. 2018;80(1):e12973. https://doi.org/10.1111/ aji. 12973 PMid:29781540

15. van Loon J, Dehghan A, Weihong T, Trompet S, McArdle WL, Asselbergs FF, et al. Genome-wide association studies identify genetic loci for low von Willebrand factor levels. Eur J Hum Genet. 2016;24(7):1035-40. https://doi.org/10.1038/ ejhg.2016.21

PMid:27307114

16. Gestational hypertension and preeclampsia: ACOG practice bulletin, number 222. Obstet Gynecol. 2020;135(6):e237-60. https://doi.org/10.1097/AOG.0000000000003891 PMid:32443079

17. Ruggeri ZM, Ware J. The structure and function of von Willebrand factor. Thromb Haemost. 1992;67(6):594-9.

PMid:1509397

18. Arshad N, Nawaz SK, lqbal R, Arshad M, Musheer F, Naz A Mushtaq I, Jaleel S. Association between genetic polymorphism and risk of von Willebrand disease in Pakistan. Biomed Res Int 2017;2017:1070471.

19. Simon D, Palatnik M, Roisenberg I. Analysis of the-1185A/G von Willebrand factor (VWF) gene polymorphism in two Brazilian ethnic groups and its effect on the plasma VWF levels. Thromb Res. 2002;105(6):519-22.

20. Dai K, Gao W, Ruan C. The Sma I polymorphism in the von Willebrand factor gene associated with acute ischemic stroke. Thromb Res. 2001;104(6):389-95. https://doi.org/10.1016/ s0049-3848(01)00389-9

PMid:11755948

21. Xu A, Xu R, Lu C, Yao M, Zhao W, Fu X, et al. Correlation of von Willebrand factor gene polymorphism and coronary heart disease. Mol Med Rep. 2012;6(5):1107-10. https://doi. org/10.3892/mmr.2012.1037 PMid:22923007

22. Saqer LS. Association between von Willebrand factor (vWF) gene polymorphism and coronary heart disease in Gaza strip. Am J Life Sci. 2016;4(2):51.

23. Berber E, Pehlevan F, Akin M, Capan OY, Kavakli K, Çaglayan SH. A common VWF exon 28 haplotype in the Turkish population. Clin Appl Thromb Hemost. 2013;19(5):550-6. https:// doi.org/10.1177/1076029612441054

PMid:22473027 